\title{
Human Congenital Infection With Trypanosoma cruzi Induces Phenotypic and Functional Modifications of Cord Blood NK Cells
}

\author{
EMMANUEL HERMANN, CRISTINA ALONSO-VEGA, AURELIE BERTHE, CARINE TRUYENS, AMILCAR FLORES, \\ MARISOL CORDOVA, LORENZO MORETTA, FAUSTINO TORRICO, VERONIQUE BRAUD, AND YVES CARLIER
}

\author{
Laboratoire de Parasitologie [E.H., A.B., CT, Y.C.], Faculté de Médecine, Université Libre de Bruxelles (ULB) B-1070 Brussels, Belgium; \\ Centro Universitario de Medicina Tropical/Laboratorio de Medicina [C.A.-V., A.F., M.C., F.T.], Faculdad de Medecina, Universidad \\ Mayor de San Simon (UMSS), Casilla 3023, Cochabamba, Bolivia; Istituto Giannina Gaslini [L.M.], 16147 Genova, Italy; Institut de \\ Pharmacologie Moléculaire et Cellulaire [V.B.], CNRS/UNSA, UMR6097, 06560 Valbonne, France
}

\begin{abstract}
We studied the phenotype and activity of cord blood natural killer (NK) cells in newborns congenitally infected with Trypanosoma cruzi. We found that the proportion of CD56 $6^{\text {bright }} \mathrm{NK}$ cells was significantly decreased in cord blood from these newborns, suggesting they may have been recruited to secondary lymphoid organs. The remaining CD56 $6^{\text {bright }} \mathrm{NK}$ cells exhibited a defective ability in the production of interferon (IFN)- $\gamma$ following in vitro activation with interleukin (IL)-12 + IL-2 or IL-12 + IL-15 cytokines, as compared with NK cells from uninfected newborns. In addition, cord blood NK cells from congenitally infected newborns stimulated with cytokines have a decreased release of granzyme B (GrB) when incubated with K562 target cells. This defect in cytotoxic effector function is associated with a reduced surface expression of activating $\mathrm{NK}$ receptors (NKp30, NKp46, and NKG2D) on CD56 ${ }^{\text {dim }}$ NK cells compared with uninfected newborns. These alterations of fetal NK cells from congenitally infected newborns may reflect a down-regulation of the NK cell response after an initial peak of activation and could also be the result of $T$. cruzi modulating the immune response. (Pediatr Res 60: 38-43, 2006)
\end{abstract}

$\mathrm{T}_{\mathrm{t}}$ he neonates and young infants are particularly susceptible to infections. This is generally considered to relate to the immaturity of their immune system defined by a low ability to generate cell-mediated immunity (1). However, the development of mature CD8 T-lymphocyte responses in newborns congenitally infected with Trypanosoma cruzi (2), the protozoa agent of Chagas disease in South America, or human cytomegalovirus (HCMV) (3), indicates that neonatal defects are not absolute. The mechanisms underlying the capacity of

Received October 12, 2005; accepted March 2, 2006

Correspondence: Yves Carlier, Laboratoire de Parasitologie, Faculté de médecine, Université Libre de Bruxelles, Route de Lennik, 808, CP 616, B-1070 Brussels, Belgium; e-mail: ycarlier@ulb.ac.be

This study was supported by the Centre de Recherche Interuniversitaire en Vaccinologie (CRIV) sponsored by the Région Wallonne and GlaxoSmithKline Biologicals (Rixensart, Belgium), by the Conseil Interuniversitaire de la Communauté française de Belgique, and the Fonds National de la Recherche Scientifique (Belgium, Convention 3.4.615.05.F).

E.H. and A.B. are research fellows at CRIV and C.A.-V. is a research fellow at the Association pour la promotion de l'éducation et la formation à l'étranger (Communauté Française de Belgique). V.B. is supported by the Centre National de la Recherche Scientifique.

Present address (E.H.): Institut National de la Santé et de la Recherche Médicale (INSERM U547), Institut Pasteur de Lille, 59019 Lille, France.

DOI: 10.1203/01.pdr.0000220335.05588.ea intracellular pathogens to induce mature cell-mediated immune responses in utero remain to be elucidated. Fetal NK cells might play an important role in the generation of the early cellular immune response during congenital infection. In adults, NK cells can directly contribute to the maturation of dendritic cells (4) and the subsequent activation of antigenspecific CD8 T-cell immune response (5). NK cell activity is regulated by a balance between opposite signals delivered by both inhibitory NK receptors (iNKRs) and activating receptors (6). In human adults, the main iNKRs include killer immunoglobulin (Ig)-like receptors (KIRs) (6), molecules known as Ig-like transcripts such as LIR1/ILT2 (7) and CD94/NKG2A (8). Activating receptors are referred to as Ig-like natural cytotoxicity receptors (NCRs) including NKp30, NKp44, NKp46 (6), and NKG2D (9).

To date, studies of human umbilical cord blood NK cells have revealed that they are immature and display low cytotoxic activity that can be partly restored by in vitro stimulation with cytokines (10). To evaluate the involvement of fetal NK cells during human congenital infection, we have studied the phenotype and activity of cord blood NK cells of newborns congenitally infected with $T$. cruzi. We observed a decrease in the frequency of CD56 ${ }^{\text {bright }} \mathrm{NK}$ cells in congenitally infected newborns. In addition, our results revealed that cord blood NK cells from congenitally infected newborns displayed a reduction in both IFN- $\gamma$ and GrB production in response to IL-12 combined with IL-2 or IL-15 and a decrease of the expression of NKp30, NKp46, and NKG2D.

\section{MATERIALS AND METHODS}

Patients. Cord blood was obtained from newborns delivered at the maternity German Urquidi (Universidad Mayor de San Simon, Cochabamba, Bolivia), while blood cell samples from healthy adults were collected from among the staff of the laboratory. Parasitological diagnosis by microscopic examination of buffy coat from cord blood collected in microhematocrit tubes and clinical examination of congenitally infected newborns were performed as previously described (11). One of the 13 studied neonates was an infant delivered by cesarean section. Four of them displayed either low birth weight only or low birth weight associated with prematurity, respiratory distress syndrome, or edema. Their lymphocyte counts were within the normal range and similar in infected and uninfected neonates. The scientific/ethic commit-

Abbreviations: CBMCs, cord blood mononuclear cells; GrB, granzyme B; NCRs,: natural cytotoxicity receptors 
tees of Universidad Mayor de San Simon and Université Libre de Bruxelles approved this study, and we obtained informed written consent of the mothers before blood collection.

Cell sample isolation. Blood was collected in endotoxin-free heparinized tubes (Becton Dickinson, Erembodegem, Belgium). Cord blood mononuclear cells (CBMCs) and peripheral blood mononuclear cells (PBMCs) from adults were then isolated by Nycoprep density gradient centrifugation (Nycomed Pharma AS, Oslo, Norway) and cryopreserved. All assays were performed with thawed cells. CD56 ${ }^{+}$cells were isolated (purity $>95 \%$ ) from cryopreserved CBMCs or PBMCs by positive selection using magnetic beads conjugated to anti-CD56 (Miltenyi Biotec, Auburn, CA).

Cell cultures. CBMCs and PBMCs $\left(0.5 \times 10^{6} / \mathrm{mL}\right)$ were cultured in polypropylene tubes containing RPMI 1640 supplemented with $10 \%$ heatinactivated fetal calf serum (FCS), $100 \mathrm{U} / \mathrm{mL}$ of penicillin $\mathrm{G}$ and $100 \mu \mathrm{g} / \mathrm{mL}$ of streptomycin (all from Cambrex Bio Science, Verviers, Belgium). Cells were stimulated either with IL-12 $(1 \mathrm{ng} / \mathrm{mL})+\mathrm{IL}-2(10 \mathrm{U} / \mathrm{mL})$ or IL-12 (1 $\mathrm{ng} / \mathrm{mL})+\mathrm{IL}-15(100 \mathrm{ng} / \mathrm{mL})$ for $24 \mathrm{~h}$ at $37^{\circ} \mathrm{C}$ in $5 \% \mathrm{CO}_{2}$ atmosphere [IL-12 and IL-15 were purchased from R\&D Systems Europe (Abingdon, United Kingdom) and IL-2 from Cambrex Bio Science]. Cells were also stimulated with live T. cruzi trypomastigotes (Tehuantepec strain) in the presence or absence of IL-15 $(1 \mathrm{ng} / \mathrm{mL})$ in a 2:1 parasite-to-cell ratio for $24 \mathrm{~h}$ at $37^{\circ} \mathrm{C}$ in $5 \% \mathrm{CO}_{2}$ atmosphere. To detect intracellular IFN- $\gamma$, we added the protein secretion inhibitor brefeldin A $(10 \mu \mathrm{g} / \mathrm{mL})$ (Sigma Chemical Co.) for the last $4 \mathrm{~h}$ of the culture.

Flow cytometry analysis. Phenotypic studies of CBMCs and PBMCs were performed by flow cytometry analysis using various combinations of the following monoclonal antibodies (MABs): CD3-PercP or -APC, CD16biotin-streptavidin-PE or -fluorescein isothiocyanate (FITC) and IFN- $\gamma$-FITC (all from Becton Dickinson). Anti-CD56-APC or -phycoerythrin (PE) and anti-NKG2A-PE (CD159a) were purchased from Coulter-Immunotech (Marseille, France) while anti-NKG2D-PE was from R\&D Systems Europe. Unconjugated anti-CD158a (EB6, anti-KIR2DL1/KIR2DS1), and -CD158b (GL183, anti-KIR2DL2/3/KIR2DS2), were obtained from CoulterImmunotech; anti-CD158e (DX9, anti-KIR3DL1), anti-CD158k (DX31, antiKIR3DL2), and anti-CD94 (DX22) were provided by DNAX (Palo Alto, CA); anti-ILT2 (CD85j) provided by D. Mason (Oxford, UK); and antiNKp30 and -NKp46 provided by L. Moretta. Data acquisition and analysis were performed using a Becton Dickinson FACScalibur flow cytometer and CELLQuest software.

GrB enzyme-linked immunospot (ELISPOT) assay. To evaluate the cytolytic activity of NK cells, we used a human GrB ELISPOT assay (Becton Dickinson). Immunospot M200 plates were coated overnight at $4^{\circ} \mathrm{C}$ with anti-human GrB capture antibody $(5 \mu \mathrm{g} / \mathrm{mL})$. The plates were then blocked with RPMI $10 \%$ FCS for $2 \mathrm{~h}$ at room temperature. After discarding medium, ELISPOT assays were performed as follows: isolated CD $3^{-} \mathrm{CD} 56^{+} \mathrm{NK}$ cells were first stimulated or not with IL-12 $(1 \mathrm{ng} / \mathrm{mL})+\mathrm{IL}-2(10 \mathrm{U} / \mathrm{mL})$ in culture medium for $24 \mathrm{~h}$ and washed before counting viable cells using trypan blue exclusion. $1 \times 10^{5} \mathrm{NK}$ cells were added into Immunospot plates and cultured for $16 \mathrm{~h}$ in the presence or absence of $1 \times 10^{4} \mathrm{~K} 562$ cell lines (LGC Promochem, Molsheim, France) as target cells (ratio: 10:1). Following cellular incubation, plates were washed and biotinylated anti-human $\mathrm{GrB}$ detection antibody was added at a final concentration of $2 \mu \mathrm{g} / \mathrm{mL}$. Plates were then incubated for $2 \mathrm{~h}$, washed three times, and horseradish peroxidase-avidin diluted 1:100 in phosphate-buffered saline containing 10\% FCS was added. After $1 \mathrm{~h}$ of incubation and washing, the spots were developed using a solution consisting of 3-amino-9-ethylcarbazole (Sigma Chemical Co.) freshly diluted 1:30 in $0.1 \mathrm{~mol} / \mathrm{L}$ of sodium acetate, $\mathrm{pH}$ 5.0. The solution was filtered and $\mathrm{H}_{2} \mathrm{O}_{2}$ was added to a final concentration of $0.0005 \%$. After incubation at room temperature for $1 \mathrm{~h}$, the number of spots was counted with an image analyzer (Carl Zeiss Vision Imaging Systems; Zeiss, Jena, Germany).

Statistical analysis. The data medians were compared between either adults or uninfected newborns or between uninfected and congenitally infected newborns by using the Mann-Whitney $U$ test. Statistical significance was accepted if $p<0.05$.

\section{RESULTS}

Decreased proportion of CD56 ${ }^{\text {bright }}$ cord blood NK cells in congenitally infected newborns. While $\mathrm{CD} 3^{-} \mathrm{CD} 56^{-} \mathrm{CD} 16^{+}$ NK cells have been described as immature cells (12), $\mathrm{CD} 3{ }^{-} \mathrm{CD} 56^{\mathrm{dim}} \mathrm{CD} 16^{+} \mathrm{NK}$ cells and $\mathrm{CD} 3^{-} \mathrm{CD} 56^{\text {bright }}$ $\mathrm{CD} 16^{\mathrm{dim} / \text { neg }} \mathrm{NK}$ cells define two functionally distinct mature NK cell subsets (13). The CD56 ${ }^{\text {bright }}$ NK cells secrete high levels of cytokines, but are poorly cytotoxic, while CD56 ${ }^{\mathrm{dim}}$ NK cells appear to be mainly cytotoxic effector cells. We have compared the proportions of these subsets between uninfected newborns $(\mathrm{M}-\mathrm{B}-)$ and healthy adults, or between uninfected and congenitally infected $(\mathrm{M}+\mathrm{B}+)$ newborns.

The main characteristics of cord blood NK cells compared with adults were that they contained a significantly higher proportion of $\mathrm{CD}^{-} \mathrm{CD}^{-} 6^{-} \mathrm{CD} 16^{+} \mathrm{NK}$ cells (Fig. 1) and expressed a higher level of CD161 (data not shown). This is consistent with an increased frequency of immature NK cells in cord blood, CD56 being expressed at later differentiation stages than CD161 (14). Interestingly, T. cruzi infection did not affect the size of the immature $\mathrm{CD} 3^{-} \mathrm{CD} 56^{-} \mathrm{CD} 16^{+}$subset of cord blood NK cells. By contrast, the congenital infection significantly decreased the proportion of CD56 ${ }^{\text {bright }} \mathrm{NK}$ cells in $\mathrm{M}+\mathrm{B}+$ newborns, a subset expanded in $\mathrm{M}-\mathrm{B}-$ cord blood compared with adults (Fig. 1). We found that the proportions of both $\mathrm{CD} 56^{\text {bright+dim }}$ and $\mathrm{CD} 56^{-} \mathrm{CD} 16^{+} \mathrm{NK}$ cells among $\mathrm{CD}^{-}$negative cells (median: $\mathrm{M}-\mathrm{B}-: 45.0 \%$, range: $29.8-69.6, n=12$ versus $\mathrm{M}+\mathrm{B}+: 41.2 \%$, range:
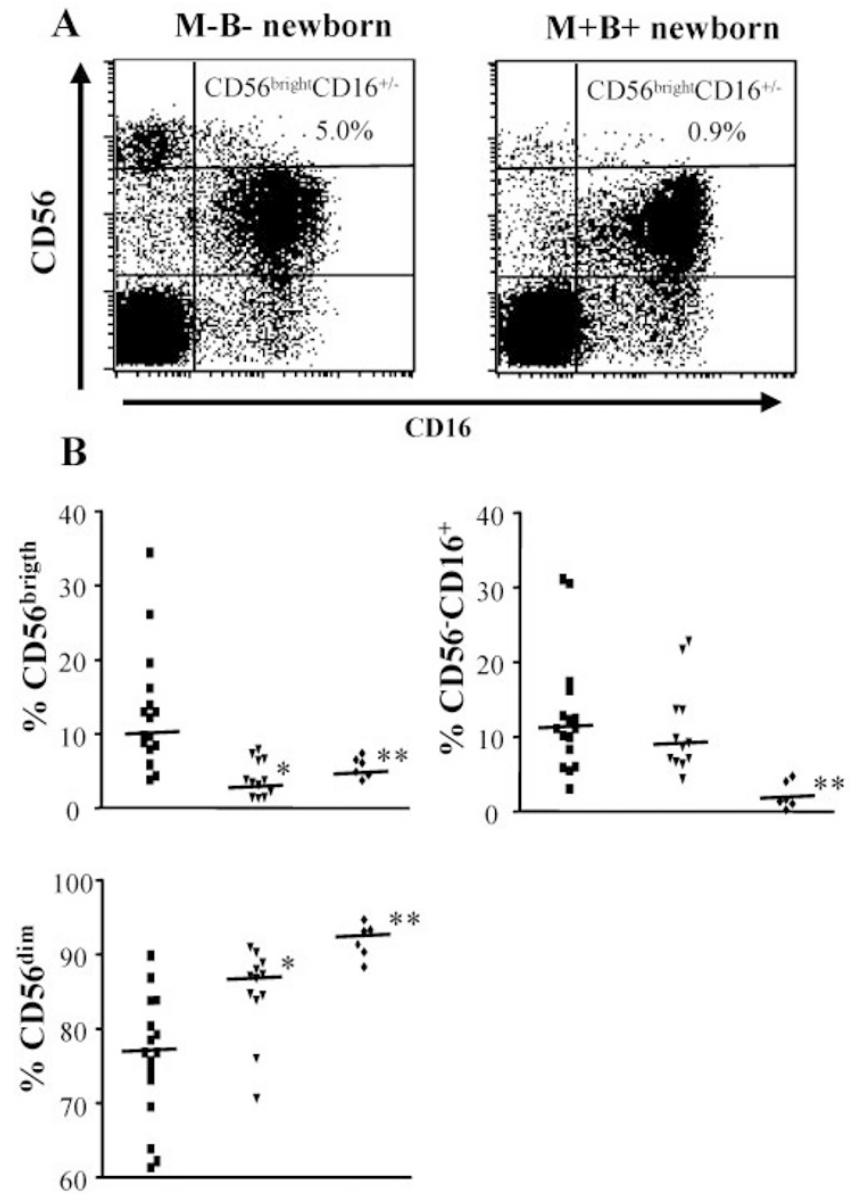

Figure 1. Analysis of NK cell subsets among CBMCs and PBMCs. (A) Representative dot plots showing the different NK cell subsets in $\mathrm{M}-\mathrm{B}-$ and $\mathrm{M}+\mathrm{B}+$ newborns. The proportion of $\mathrm{CD} 56^{\text {bright }} \mathrm{CD} 16^{+/-} \mathrm{NK}$ cells among $\mathrm{CD}^{-}$negative cells is indicated. $(B)$ Individual data with the percentages for all $\mathrm{NK}$ cell subsets among $\mathrm{CD} 3^{-} \mathrm{CD} 56^{+/-} \mathrm{NK}$ cells in $\mathrm{M}-\mathrm{B}-($ squares, $n=$ 16 ) or in $\mathrm{M}+\mathrm{B}+$ newborns (triangles, $n=12$ ) and in adults (diamonds, $n=$ 6); bars indicate the median; $* p<0.01 \mathrm{M}-\mathrm{B}-v s \mathrm{M}+\mathrm{B}+$ newborns; ** $p<$ $0.01 \mathrm{M}-\mathrm{B}-v s$ adults. 
27.0-60.5, $n=11$ ) were unchanged between groups of newborns. The level of total lymphocytes being similar to those of the controls, these data suggest that the decreased proportion of CD56 $6^{\text {bright }} \mathrm{NK}$ cells in congenitally infected newborns likely reflects a loss of these cells and is not due to an increase in absolute numbers of CD56 $6^{\mathrm{dim}} \mathrm{NK}$ cells.

Defective IFN- $\gamma$ production by $C^{2} 56^{\text {bright }}$ cord blood NK cells from congenitally infected newborns. CBMCs or $\mathrm{PB}-$ MCs were stimulated with IL-12 + IL-2 or IL-12 + IL-15 for $24 \mathrm{~h}$, and the intracellular content of IFN- $\gamma$ was measured among CD56 $6^{\text {bright }}$ NK cells (Fig. 2). The unstimulated cells did not produce IFN- $\gamma$ (data not shown), while the addition of both combination of cytokines widely increased the frequency of CD56 $6^{\text {bright }}$ NK cells producing IFN- $\gamma$ in uninfected newborns and adults. The frequency of cord blood CD56 $6^{\text {bright }} \mathrm{NK}$ cells that produce IFN- $\gamma$ in response to IL- $12+$ IL-2 and to a lesser extent IL-12 + IL-15 was significantly reduced in $\mathrm{M}+\mathrm{B}+$ newborns compared with $\mathrm{M}-\mathrm{B}-$ newborns. These results demonstrate that congenital infection with $T$. cruzi was associated with cord blood CD56 ${ }^{\text {bright }} \mathrm{NK}$ cells producing very low level of IFN- $\gamma$ in response to cytokine stimulation.

We also tested whether in vitro exposure of cord blood NK cells to live $T$. cruzi could trigger secretion of IFN- $\gamma$. For this

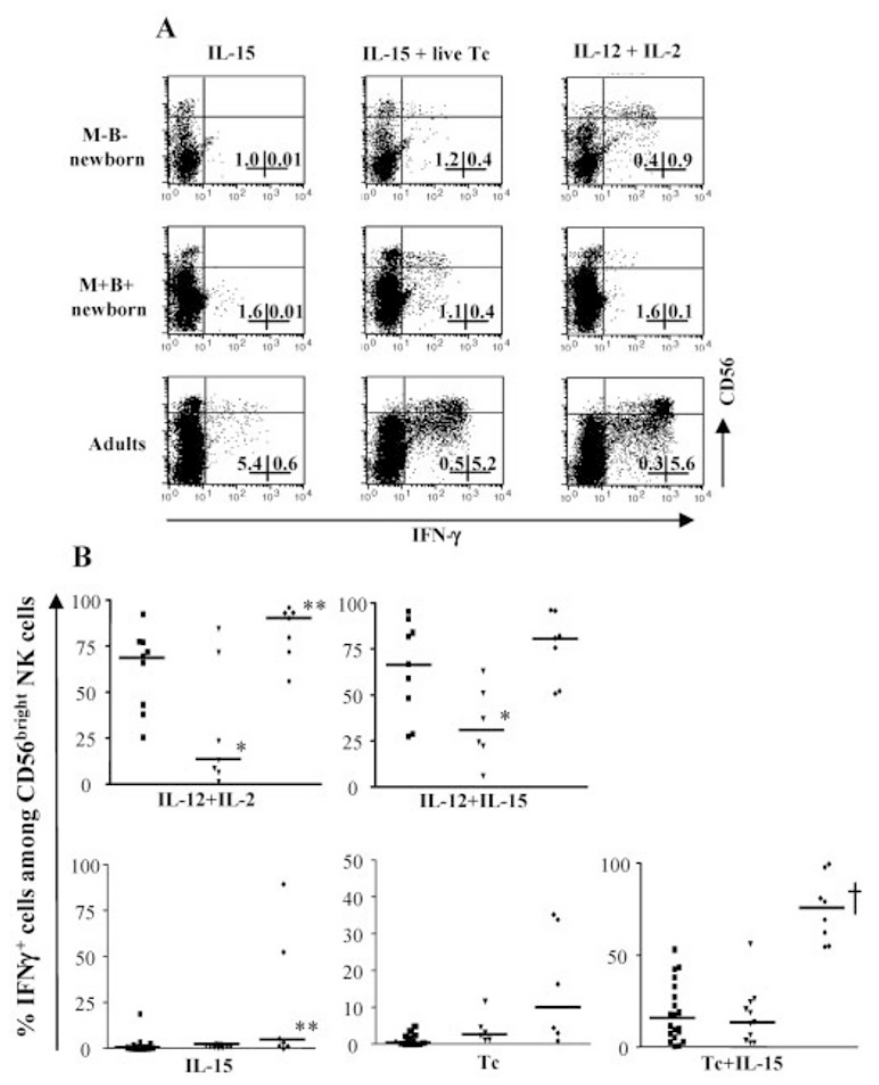

Figure 2. IFN- $\gamma$ production by NK cells. CBMCs or PBMCs were stimulated with IL-12 in combination with either IL-2 or IL-15 for $24 \mathrm{~h}$, with IL-15 and live T. cruzi (Tc) alone or in combination. (A) Representative dot plots showing IFN- $\gamma$ production. The proportion of $\mathrm{CD}^{-}{ }^{-} \mathrm{CD} 56^{\text {bright }} \mathrm{NK}$ cells positive or not for IFN- $\gamma$ is indicated. (B) Individual data and median of percentages of IFN- $\gamma$ positive cells among $\mathrm{CD}^{-}{ }^{-} \mathrm{CD} 56^{\text {bright }} \mathrm{NK}$ cells from $\mathrm{M}-\mathrm{B}-$ (squares, $n=9$ ) or from $\mathrm{M}+\mathrm{B}+$ (triangles, $n=6$ ) newborns or adults (diamonds, $n=6$ ) are shown; $* p<0.05 \mathrm{M}-\mathrm{B}-v s \mathrm{M}+\mathrm{B}+$ newborns; ** $p<0.05 \mathrm{M}-\mathrm{B}-v s$ adults; $\dagger p<0.01 \mathrm{M}-\mathrm{B}-v s$ adults. purpose, CBMCs and PBMCs were incubated with live $T$. cruzi alone or in combination with IL-15 for $24 \mathrm{~h}$ (Fig. 2). In contrast to cord blood NK cells, NK cells from some adults could produce a large amount of IFN- $\gamma$ after stimulation with T. cruzi alone. IFN- $\gamma$ was more easily detected when IL-15 was added with parasites into the culture medium. In this last condition, a majority of CD56 $6^{\text {bright }} \mathrm{NK}$ cells from adults secreted IFN- $\gamma$ while the proportion of cord blood CD $56^{\text {bright }}$ NK cells from both groups of newborns that did produce IFN- $\gamma$ was reduced (Fig. 2). These data demonstrate that cord blood NK cells can produce IFN- $\gamma$ upon stimulation with live parasites in vitro without significant differences between uninfected and infected newborns.

Reduced cytolytic activity of CD56 ${ }^{\text {dim }}$ cord blood NK cells from congenitally infected newborns. We investigated whether GrB production by cord blood NK cells could also be affected in $\mathrm{M}+\mathrm{B}+$ newborns. $\mathrm{GrB}$ release in response to IL-12 + IL-2 stimulation was measured by ELISPOT against the NK sensitive-target cell line K562. As a control, purified $\mathrm{CD}^{+} 6^{+}$NK cells stimulated with IL-12 + IL-2 produced low number of spots in the absence of K562 cells in both newborns and adults (data not shown). As shown in two independent experiments with different donors (Fig. 3), the addition of target cells to NK cells induced GrB release in uninfected newborns and adults. By contrast, NK cells from congenitally infected newborns displayed a lower level of GrB spots, suggesting a reduced cytotoxic potential.

Congenital T. cruzi infection is associated with decreased expression of $\mathrm{NK}$ cell-activating receptors on cord blood CD56 $^{\text {dim }}$ NK cells. We also investigated whether the presence of live parasites in congenitally infected newborns could have affected the expression of activating NK receptors (NKp30, NKp46, and NKG2D) on NK cells (Fig. 4). The level of expression of NCRs tended to be higher in $\mathrm{M}-\mathrm{B}-$ newborns than in adults as well as the density of NKG2D and NKp30 among cord blood CD56 ${ }^{\text {bright }}$ NK cells (Fig. $4 A$ and $B$ ). Interestingly, $T$. cruzi infection was associated with a modulation of activating $\mathrm{NK}$ receptor expression on CD56 ${ }^{\mathrm{dim}} \mathrm{NK}$ cells. Figure $4(A, C$, and $E$ ) shows a lower mean density of

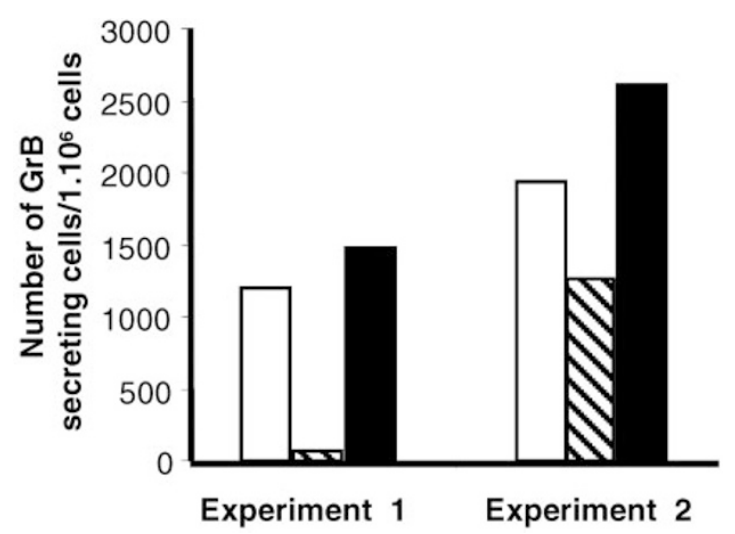

Figure 3. NK cell cytotoxic activity. Purified $\mathrm{CD}^{+} 6^{+} \mathrm{NK}$ cells were stimulated for $24 \mathrm{~h}$ with IL-12 + IL-2 before being incubated with K562 cells for $16 \mathrm{~h}$ into Immunospot plates. Two independent experiments are represented. Black, white, and hatched histograms represent results obtained in adults, uninfected $(\mathrm{M}-\mathrm{B}-)$ and $T$. cruzi-infected newborns $(\mathrm{M}+\mathrm{B}+)$, respectively. 


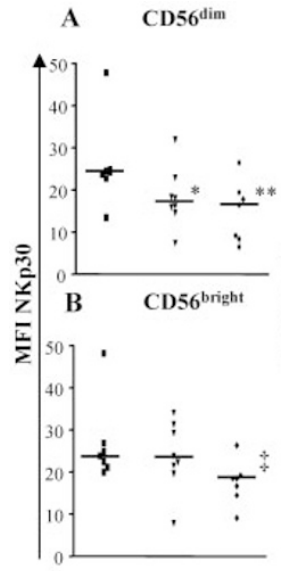

C
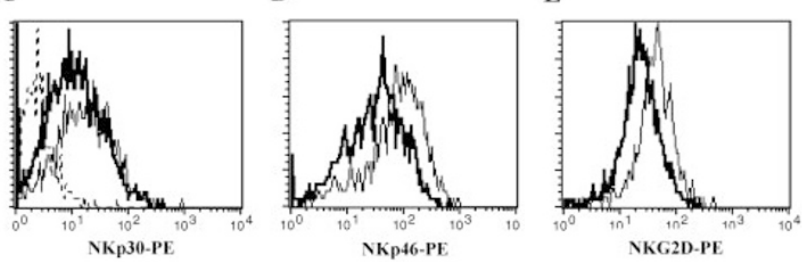

Figure 4. Expression of activating NK receptors. $(A$ and $B$ ) Individual data and median of the mean fluorescence intensity (MFI) of NKp30, NKp46, and NKG2D, respectively, on $\mathrm{CD} 3^{-} \mathrm{CD} 56^{\mathrm{dim}}$ and $\mathrm{CD} 3^{-} \mathrm{CD} 56^{\text {bright }} \mathrm{NK}$ cells from $\mathrm{M}-\mathrm{B}-($ squares, $n=7)$ and $\mathrm{M}+\mathrm{B}+($ triangles, $n=9)$ newborns or adults (diamonds, $n=7$ ); * $p<0.05, \mathrm{M}-\mathrm{B}-v s \mathrm{M}+\mathrm{B}+$ newborns; ** $p<0.05$, $\mathrm{M}-\mathrm{B}-v s$ adults; $\dagger p<0.01, \mathrm{M}-\mathrm{B}-v s \mathrm{M}+\mathrm{B}+; \ddagger p<0.01, \mathrm{M}-\mathrm{B}-v s$ adults. $(C, D$, and $E$ ) Representative histogram staining of NKp30, NKp46, and NKG2D molecules among total NK cells from one $\mathrm{M}-\mathrm{B}-$ (thin lines) and from one $\mathrm{M}+\mathrm{B}+$ (bold lines); the peak with dashed lines $(A)$ represents the staining with a matched MAB isotype.

expression of NKp30 and NKG2D in $\mathrm{M}+\mathrm{B}+$ newborns compared with $\mathrm{M}-\mathrm{B}-$ newborns. More strikingly, a significant down-regulation of the mean surface density of NKp46 was detected in $\mathrm{M}+\mathrm{B}+$ newborns that led to a level of expression twice less intense than those of control newborns (Fig. $4 A$ and $D$ ). By contrast, the expression of activating NK receptors on cord blood CD56 ${ }^{\text {bright }}$ NK cells was more stable. Taken together, these results show the pattern of NCRs expression in $\mathrm{M}+\mathrm{B}+$ newborns resemble that observed in adults with a reduced surface density of NK cells expressing NKp30 and NKp46 compared with uninfected newborns.

Expression of inhibitory NK cell receptors on cord blood NK cells is not significantly modulated by congenital infection. In addition to activating receptors, we studied the surface expression of KIR (CD158a, CD158b, CD158e, CD158k), ILT-2 (CD85j), and CD94/NKG2A (CD94/CD159a) inhibitory NK receptors. Of note, CD158a and CD158b MABs also recognize activating $\mathrm{CD} 158 \mathrm{~h}$ and $\mathrm{CD} 158 \mathrm{j}$ NK receptors, respectively. Most of CD56 ${ }^{\text {bright }}$ NK cells $(90-100 \%)$ were found to express high levels of CD94/NKG2A, and little KIR and ILT2, in all newborns and adults without any difference between groups (data not shown). The expression of NKG2A was up-regulated on CD56 ${ }^{\mathrm{dim}}$ cord blood NK cells compared with adults (Fig. 5), but the congenital infection with $T$. cruzi did not affect the expression of this inhibitory receptor. The expression of KIRs was essentially found on CD56 $6^{\mathrm{dim}} \mathrm{NK}$ cells and Figure 5 shows that the frequency of CD158a,

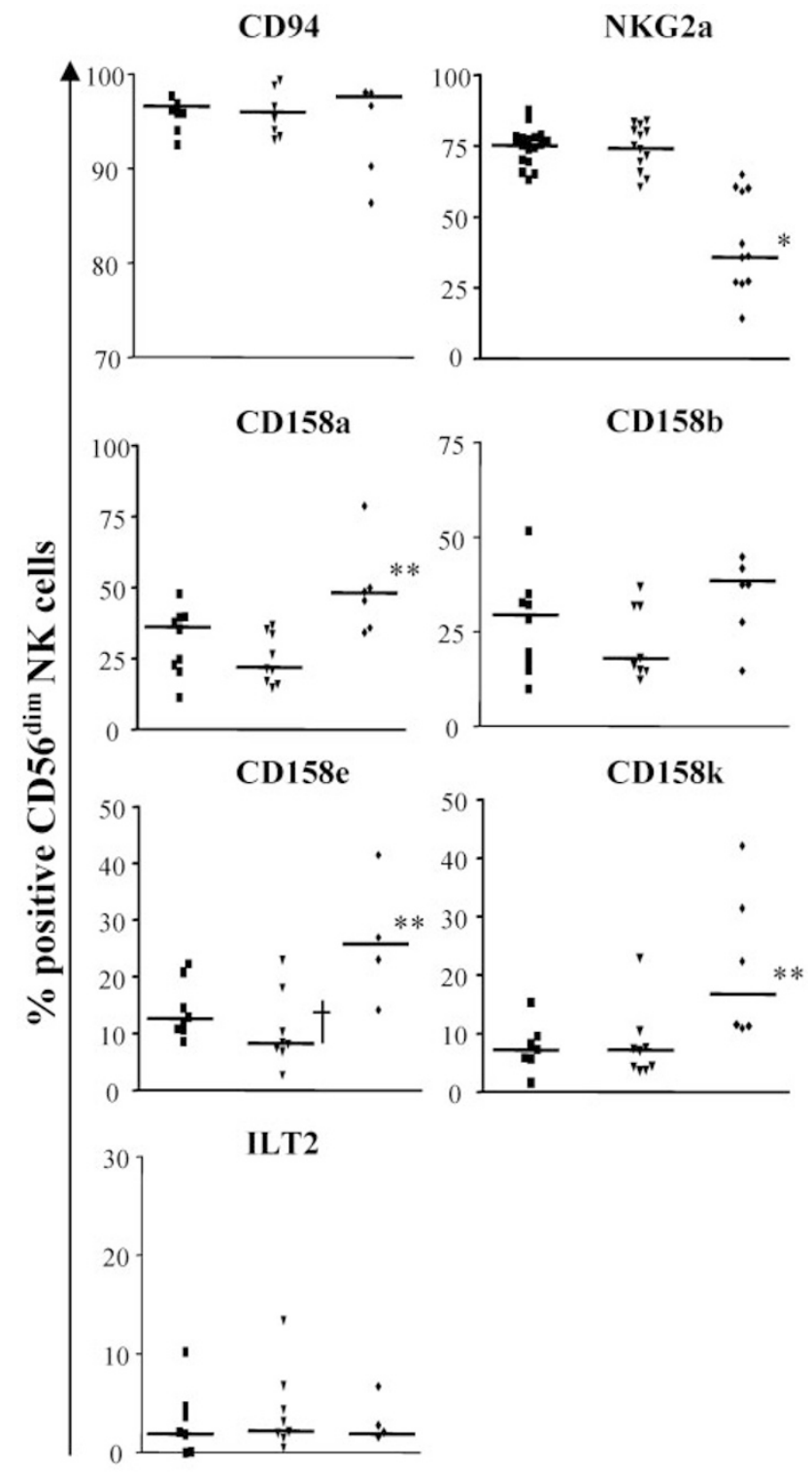

Figure 5. Expression of inhibitory NK receptors. Figures indicate the individual data and the median proportions of positive NK cells; for CD94, $\mathrm{CD} 158 \mathrm{a}, \mathrm{b}$, e and $\mathrm{k}$, and ILT2: M-B- (squares), $n=7-9 ; \mathrm{M}+\mathrm{B}+$ (triangles), $n=7-9$; adults (diamonds), $n=4-6$; for NKG2A (M-B-: $n=18$; $\mathrm{M}+\mathrm{B}+: n=13$; adults: $n=11) ; * p<0.01, \mathrm{M}-\mathrm{B}-v s$ adults; $* p<0.05$ $\mathrm{M}-\mathrm{B}-v s$ adults; $\uparrow p<0.05, \mathrm{M}-\mathrm{B}-v s \mathrm{M}+\mathrm{B}+$.

CD158e, and CD158k was globally lower in $\mathrm{M}-\mathrm{B}-$ cord blood compared with adults. The expression of KIR or ILT2 was not profoundly altered between both groups of newborns, although the expression of CD158a, CD158b, and CD158e tended to be down-regulated in congenitally infected newborns. We cannot, however, conclude whether CD158a and b down-modulation is due to a decreased of the inhibitory and/or the activating form of KIR. Globally, these results suggest that inhibitory NK cell receptor expression is not correlated with congenital infection by $T$. cruzi.

\section{DISCUSSION}

To characterize the phenotype and function of cord blood NK cells during infection, we studied newborns infected in 
utero with $T$. cruzi and presenting a patent parasitemia at birth. Our work demonstrates a loss of circulating CD $56^{\text {bright }} \mathrm{NK}$ cells in such congenitally infected newborns. The remaining cord blood NK cells displayed a reduced ability to perform effector functions as well as a reduced expression of NCRs and NKG2D on CD56 $6^{\mathrm{dim}}$ NK cells.

Various hypotheses can be considered to explain alterations of cord blood NK cells in newborns congenitally infected with T. cruzi. One possibility to account for their weak response to IL-12 combined with either IL-15 or IL-2 relates to a defect in the IL-12 signaling pathway. However, both the expression of IL-12R $\beta 1$ on resting NK cells and the ability of IL-12 and IL-2 to up-regulate the expression of IL- $12 R \beta 2$ on CD56 ${ }^{\text {bright }}$ NK cells were not altered in infected newborns (data not shown), arguing against a generalized NK cell defect in response to IL-12.

A second possibility relates to the level of expression of activating NK receptors because a strict correlation between NCR density and NK cell mediated cytotoxicity has been reported in vitro (15). Indeed, a decreased surface expression of NKp30, NKp46, and NKG2D on cord blood CD56 ${ }^{\operatorname{dim}} \mathrm{NK}$ cells was observed in congenitally infected newborns, in agreement with previous reports of patients infected with human immunodeficiency virus (16) or with acute myelogenous leukemia (17). Because CD56 ${ }^{\mathrm{dim}} \mathrm{NK}$ cells were the main cells involved in NK cytotoxic functions, these alterations in the level of activating NK receptors might contribute to the defective release of $\mathrm{GrB}$ in the presence of K562 cells. In addition, the decreased surface expression of NKG2D in congenitally infected newborns might be the result of direct contact with its natural ligands (18). Alternatively, this downmodulation might also be mediated by soluble factors such as transforming growth factor- $\beta$ (TGF- $\beta$ ), a cytokine known to down-regulate the surface expression of NKp30 and NKG2D (19). Of note, $T$. cruzi needs to activate the TGF- $\beta$ signaling pathway to infect cells (20), thus possibly modulating the expression of receptors triggering NK cell activation. Whether the reduced expression of NK cell-activating receptors in infected newborns is induced by exposure to foreign pathogens and could be a way to evade the host innate immune response remains an interesting and open question.

Finally, a third possibility relates to the selective loss of activated CD56 ${ }^{\text {bright }} \mathrm{NK}$ cell subsets in CBMCs of congenitally infected newborns, either due to their migration from the periphery to secondary lymphoid organs or to sites of infection $(21,22)$ or through apoptosis. It has indeed been shown that in vitro stimulation of NK cells by IL-15 or IL-2 + IL12 induces early IFN- $\gamma$ and tumor necrosis factor- $\alpha$ (TNF- $\alpha$ ) production followed by NK cell apoptosis and a decline in cytokine production (23) and that NK cell functions were inhibited after IL-12 priming (24). These data, as well as others obtained in mice $(25,26)$, suggest that fetal NK cells were submitted to a primary activation following in utero infection before their effector functions were down-regulated, as part of a homeostatic control of the NK cell response after an initial peak of activation.

Experimental models have shown that NK cells play a crucial role in immunity against $T$. cruzi (27). However, the role of NK cells during human T. cruzi infection is still unclear. Indeed, our study is the first to show the ability of $T$. cruzi to induce IFN- $\gamma$ production by human adult NK cells. This is consistent with the ability of other parasites to activate these cells $(28,29)$. The low production of IFN- $\gamma$ by cord blood NK cells following $T$. cruzi stimulation in vitro may be attributed to their immaturity, as revealed by the high proportion of NK cells positive for CD161 and NKG2A (14) compared with adults. However, we extend these results by showing that in vitro stimulation with live T. cruzi and IL-15 led to higher IFN- $\gamma$ production by neonatal NK cells. Indeed, in vivo, live parasites are present in congenitally infected newborns, and IL-15, although in lower amounts than in adults, is also produced by cord blood cells (30). Although the direct cytotoxicity of cord blood NK cells against $T$. cruzi was not investigated in the present work, this indicates that neonatal NK cells, at least as a potential source of IFN- $\gamma$, might be involved in early life immunity against intracellular pathogens.

On the other hand, it could be considered that alterations of NK cell function and/or of NCRs and NKG2D expression in $\mathrm{M}+\mathrm{B}+$ newborns could have contributed to their susceptibility to congenital infection. However, we have previously shown that congenitally infected newborns were able to generate a parasite-specific CD8 T-cell response (2), arguing against an initial immunodeficiency, like this suggesting that their NK-cell immune response is most likely effective.

In conclusion, the cord blood NK cell response appears to be reduced after congenital transmission of $T$. cruzi. It remains to clarify whether this impaired NK cell immune response is a physiological result of their early participation in the fetal immune response or whether the presence of live $T$. cruzi modulates the immune response, which could represent a way for the parasite to improve its survival into the host.

Acknowledgments. We thank Eduardo Suarez and the staff of the maternity German Urquidi (Cochabamba, Bolivia) for the management of patients; Mary-Cruz Torrico, Rudy Parrado, Miguel Guzman, and Marco Antonio Solano (CUMETROP/LABIMED, UMSS, Cochabamba, Bolivia) for performing the serological and parasitological diagnosis of patients; and Virginie Verscheure (Vaccine and Mucosal Unit, Erasme Hospital, Brussels, Belgium) for helping in ELISPOT analysis. We are grateful to Valérie Verhasselt, Eric Muraille, and Franck Remoue for their comments on the manuscript.

\section{REFERENCES}

1. Adkins B, Leclerc C, Marshall-Clarke S 2004 Neonatal adaptive immunity comes of age. Nat Rev Immunol 4:553-564

2. Hermann E, Truyens C, Alonso-Vega C, Even J, Rodriguez P, Berthe A, GonzalezMerino E, Torrico F, Carlier Y 2002 Human fetuses are able to mount an adultlike CD8 T-cell response. Blood 100:2153-2158

3. Marchant A, Appay V, Van der Sande M, Dulphy N, Liesnard C, Kidd M, Kaye S, Ojuola O, Gillespsie GM, Vargas Cuero AL, Cerundolo V, Callan M, McAdam KP, Rowland-Jones SL, Donner C, McMichael AJ, Whittle H 2003 Mature CD8(+) T lymphocyte response to viral infection during fetal life. J Clin Invest 111:1747-1755

4. Cooper MA, Fehniger TA, Fuchs A, Colonna M, Caligiuri MA 2004 NK cell and DC interactions. Trends Immunol 25:47-52

5. Geldhof AB, Van Ginderachter JA, Liu Y, Noel W, Raes G, De Baetselier P 2002 Antagonistic effect of NK cells on alternatively activated monocytes: a contribution of NK cells to CTL generation. Blood 100:4049-4058 
6. Moretta L, Moretta A 2004 Unravelling natural killer cell function: triggering and inhibitory human NK receptors. EMBO J 23:255-259

7. Shiroishi M, Tsumoto K, Amano K, Shirakihara Y, Colonna M, Braud VM, Allan DS, Makadzange A, Rowland-Jones S, Willcox B, Jones EY, van der Merwe PA, Kumagai I, Maenaka K 2003 Human inhibitory receptors Ig-like transcript 2 (ILT2) and ILT4 compete with CD8 for MHC class I binding and bind preferentially to HLA-G. Proc Natl Acad Sci U S A 100:8856-8861

8. Braud VM, Allan DS, O'Callaghan CA, Soderstrom K, D'Andrea A, Ogg GS, Lazetic S, Young NT, Bell JI, Phillips JH, Lanier LL, McMichael AJ 1998 HLA-E binds to natural killer cell receptors CD94/NKG2A, B and C. Nature 391:795-799

9. Bauer S, Groh V, Wu J, Steinle A, Phillips JH, Lanier LL, Spies T 1999 Activation of NK cells and T cells by NKG2D, a receptor for stress-inducible MICA. Science 285:727-729

10. Gaddy J, Risdon G, Broxmeyer HE 1995 Cord blood natural killer cells are functionally and phenotypically immature but readily respond to interleukin-2 and interleukin-12. J Interferon Cytokine Res 15:527-536

11. Torrico F, Alonso-Vega C, Suarez E, Rodriguez P, Torrico MC, Dramaix M, Truyens C, Carlier Y 2004 Maternal Trypanosoma cruzi infection, pregnancy outcome, morbidity, and mortality of congenitally infected and non-infected newborns in Bolivia. Am J Trop Med Hyg 70:201-209

12. Gaddy J, Broxmeyer HE 1997 Cord blood CD16+56- cells with low lytic activity are possible precursors of mature natural killer cells. Cell Immunol 180:132-142

13. Cooper MA, Fehniger TA, Caligiuri MA 2001 The biology of human natural killer-cell subsets. Trends Immunol 22:633-640

14. Bennett IM, Zatsepina O, Zamai L, Azzoni L, Mikheeva T, Perussia B 1996 Definition of a natural killer NKR-P1A+/CD56-/CD16- functionally immature human NK cell subset that differentiates in vitro in the presence of interleukin 12. J Exp Med 184:1845-1856

15. Sivori S, Falco M, Marcenaro E, Parolini S, Biassoni R, Bottino C, Moretta L, Moretta A 2002 Early expression of triggering receptors and regulatory role of 2B4 in human natural killer cell precursors undergoing in vitro differentiation. Proc Natl Acad Sci U S A 99:4526-4531

16. De Maria A, Fogli M, Costa P, Murdaca G, Puppo F, Mavilio D, Moretta A, Moretta L 2003 The impaired NK cell cytolytic function in viremic HIV-1 infection is associated with a reduced surface expression of natural cytotoxicity receptors (NKp46, NKp30 and NKp44). Eur J Immunol 33:2410-2418

17. Costello RT, Sivori S, Marcenaro E, Lafage-Pochitaloff M, Mozziconacci MJ, Reviron D, Gastaut JA, Pende D, Olive D, Moretta A 2002 Defective expression and function of natural killer cell-triggering receptors in patients with acute myeloid leukemia. Blood 99:3661-3667
18. Groh V, Wu J, Yee C, Spies T 2002 Tumour-derived soluble MIC ligands impair expression of NKG2D and T-cell activation. Nature 419:734-738

19. Castriconi R, Cantoni C, Della CM, Vitale M, Marcenaro E, Conte R, Biassoni R, Bottino C, Moretta L, Moretta A 2003 Transforming growth factor beta 1 inhibits expression of NKp30 and NKG2D receptors: consequences for the NK-mediated killing of dendritic cells. Proc Natl Acad Sci U S A 100:4120-4125

20. Ming M, Ewen ME, Pereira ME 1995 Trypanosome invasion of mammalian cells requires activation of the TGF beta signaling pathway. Cell 82:287-296

21. Moretta A 2002 Natural killer cells and dendritic cells: rendezvous in abused tissues. Nat Rev Immunol 2:957-964

22. Fehniger TA, Cooper MA, Nuovo GJ, Cella M, Facchetti F, Colonna M, Caligiuri MA 2003 CD56bright natural killer cells are present in human lymph nodes and are activated by T cell-derived IL-2: a potential new link between adaptive and innate immunity. Blood 101:3052-3057

23. Ross ME, Caligiuri MA 1997 Cytokine-induced apoptosis of human natural killer cells identifies a novel mechanism to regulate the innate immune response. Blood 89:910-918

24. Wang KS, Frank DA, Ritz J 2000 Interleukin-2 enhances the response of natural killer cells to interleukin-12 through up-regulation of the interleukin-12 receptor and STAT4. Blood 95:3183-3190

25. Pien GC, Biron CA 2000 Compartmental differences in NK cell responsiveness to IL-12 during lymphocytic choriomeningitis virus infection. J Immunol 164:9941001

26. Robbins SH, Tessmer MS, Mikayama T, Brossay L 2004 Expansion and contraction of the NK cell compartment in response to murine cytomegalovirus infection. J Immunol 173:259-266

27. Lieke T, Graefe SE, Klauenberg U, Fleischer B, Jacobs T 2004 NK cells contribute to the control of Trypanosoma cruzi infection by killing free parasites by perforinindependent mechanisms. Infect Immun 72:6817-6825

28. Artavanis-Tsakonas K, Eleme K, McQueen KL, Cheng NW, Parham P, Davis DM, Riley EM 2003 Activation of a subset of human NK cells upon contact with Plasmodium falciparum-infected erythrocytes. J Immunol 171:5396-5405

29. Nylen S, Maasho K, Soderstrom K, Ilg T, Akuffo H 2003 Live Leishmania promastigotes can directly activate primary human natural killer cells to produce interferon-gamma. Clin Exp Immunol 131:457-467

30. Qian JX, Lee SM, Suen Y, Knoppel E, van de Ven C, Cairo MS 1997 Decreased interleukin-15 from activated cord versus adult peripheral blood mononuclear cells and the effect of interleukin-15 in upregulating antitumor immune activity and cytokine production in cord blood. Blood 90:3106-3117 